\title{
Determination of Climate and Social Community Factors in Coronavirus Disease-19 Spread Distribution
}

\author{
Faradiba Faradiba ${ }^{1 *(D)}$, Lodewik Zet $^{2}$ (D) \\ ${ }^{1}$ Department of Physics Education, Universitas Kristen Indonesia, Jakarta, Indonesia; ${ }^{2}$ Directorate Statistic of Life Stock, \\ Fisheries and Forestry, BPS-Statistics Indonesia, Jakarta, Indonesia
}

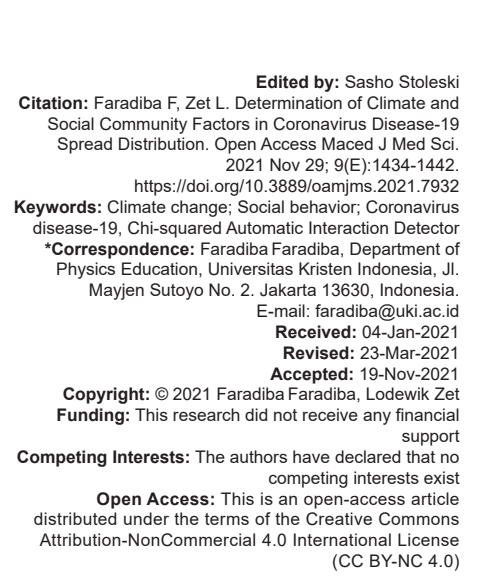

\section{Abstract}

BACKGROUND: Coronavirus Disease-2019 (COVID-19) is very shocking to the world. Until mid-2020, this virus has not yet found a vaccine that can be produced and can be applied en mass across the country. The spread of COVID-19 differs between regions which implie that regional characteristics have an influence on the rate of growth. Regional and social climate factors are thought to have a role in the growth rate of COVID-19.

AIM: This study aims to find the role of climate and social society on the spread of COVID-19.

METHODS: This research uses OLS regression analysis method, and then continued with Chi-squared Automatic Interaction Detector analysis to find the segmentation of the role of climate and social factors on the daily growth rate of COVID-19 in positive and deceased patients.

RESULTS: The results of this study state that all independent variables of the study have a significant effect on the spread of COVID-19, with R-squared values in positive and deceased patients, respectively $61.1 \%$ and $70.0 \%$. Strategic steps are needed to carry out policies that are targeted, effective and efficient.

CONCLUSION: The results of this study can be a reference for the government in determining policies to reduce the growth rate of COVID-19, by focusing on areas that have poor sanitary environment and area are on Java Island.

\section{Introduction}

Coronavirus Disease-2019 (COVID-19) which occurred at the end of 2019 was very shocking to the world. Until mid-2020, this virus has not yet found a vaccine that can be produced and can be applied en mass across the country. This causes the speed of development of positive cases and death due to COVID-19 uncontrolled in some countries [1]. Not yet found the right vaccine and the growth of positive cases that are rising and will disrupt various aspects of people's lives and the economy of a country [2], [3], [4], [5], [6].

In spreading positive cases of COVID-19, it is necessary to consider factors that are naturally occurring, such as the climate of a region. In early 2020, many people stated that COVID-19 would be difficult to develop in tropical countries [7], [8]. However, it turns out that it is not in accordance with the existing reality. Until mid-2020, the growth of positive cases has not been controlled optimally, such as in Indonesia. Indonesia has a tropical climate, but in regions that have an extreme climate, the spread of COVID-19 is above the provincial average.

Over time, there are regions that have relatively sloping positive case growth. This is due to government efforts and community participation [9]. The focus is on the community. Because through good behavior control, it certainly will reduce the rate of spread in an area. In Indonesia, there are large provinces that have high growth rates. In fact, it is known from socioeconomic indicators, these provinces have a good trend.

At the end of September 2020, according to the Ministry of Health, the spread of COVID-19 in Indonesia is still uncertain. Due to the addition of cases continues to reach a record high. The Ministry of Health recorded 287,008 people who were positive and 10,740 people who had died. COVID-19 has spread to all provinces in Indonesia, and only 17 out of 514 districts/cities have not been exposed.

In practice, the government issued a number of rules that were intended to restrict the community from interacting. As a statement often made by President Jokowi, that people are asked to worship at home, work from home, and school from home. This is considered appropriate at the beginning of the application [10], [11]. However, over time people who depend on social interaction, must leave the house to get a source of income [12], [13]. This caused a number of regions to experience a drastic increase [14]. This character and culture has been embedded through the social conditions of the community [15], [16]. 
Some media always tell how to break the chain of COVID-19 distribution [17], but there are still many people who ignore that information. Communities in urban areas that incidentally have better access to information tend to ignore these appeals. Whereas in urban areas, it is a region that tends to be dense. Hence, if there is an exponential spread of COVID-19, the numbers will be very large, compared to rural communities [18].

The synergy of natural factors, which in this study is indicated by climate, and social conditions play a major role in the spread of COVID-19 [19]. There have been many studies reviewing the climate relationship on the spread of COVID-19 at the country level [20], [21], [22]. However, there is still limited research that analyzes the role of climate and social factors on the spread of COVID-19 using village level data. Therefore, the expected outcome of this research is to find out the role of climate and social community on the spread of COVID-19. The results of this study describe the independent variables together have a significant effect on the daily spread of COVID-19 (for 70 days from March 20 to May 29, 2020) in Indonesia, both in positive patients and deaths due to COVID-19. This study uses 24 independent variables, including: rainfall, temperature, solar radiation, environmental conditions, access to TV broadcasts, cell phone use, ethnic diversity, the existence of public facilities, development programs and empowerment in the community, and a number of control variables that are also affects the spread of COVID-19. This research will also review what indicators need to be the focus of attention so that the spread of COVID-19 can be reduced to a minimum.

There are several factors that influence the spread of COVID-19 when viewed from the climate and social aspects. When this aspect can be anticipated and controlled well in all regions, it will produce preliminary information on the acceleration of the spread of COVID-19 which has characteristics in accordance with the research variables.

Climate change is a change in the average weather over a relatively long period. In modern terms, the term climate change is also known as global warming, which causes geothermal heat to increase. The heat conditions tend to be felt by the people in the area crossed by the equator [23]. Indonesia is one of the countries in the world that is crossed by the equator. Phenomena that occur around the equator, including sunlight in the equatorial region fell to the ground at an angle of 90 degrees. This angle of falling sunlight makes solar power falling per unit area larger so that the area around the equator is hotter. Sunlight is almost always located above the equator, so temperatures below the equator are always high.

In recent times, extreme climate changes can pose a threat to human health caused by viruses [24]. This happened in a previous epidemic, which stated that changes in temperature, rainfall, and humidity could have a positive influence on the spread of infectious diseases. This climate change can also extend the life cycle of viruses [25], [26].

In Indonesia, climate change is causing an increase in dengue cases caused by the dengue virus which is transmitted through mosquito bites. During the first time, there were dengue fever cases in Indonesia, up to March 2020 there had been more than 16,000 cases. Even an extraordinary event (KLB) was set in Sikka District because of this outbreak. Climate change contributes to increased rainfall, which causes a large amount of standing water as a breeding ground for mosquitoes. Humidity also affects the flight distance and age of mosquitoes. This is one case of a disease caused by a virus, while many other infectious viral diseases, not least the COVID-19 pandemic that has been taking place since early 2020 [27], [28], [29].

At present, it is very difficult to predict climate change and the spread of viruses in the future. This is due to the complexity of interactions between climate, nature, and human activities. According to earlier research on climate change, human activity has caused about $1.0^{\circ} \mathrm{C}$ of global warming. If this condition continues, the temperature will reach $1.5^{\circ} \mathrm{C}$ and even more in 2030 to 2052 . As a result, there will be many droughts, floods, and heat waves. Climate change will also have an influence on the world's animals and ecosystems. In the process of spreading, there are animals that carry viruses and infect humans. In accordance with the world disasters being faced, no evidence that climate change has a role in the spread of COVID-19, but there is debate about the possibility of climate factors in the spread of COVID-19.

Based on a report from the WHO, "Current climate change, is one of the changes that occur globally, is estimated to have various impacts on the transmission of disease in humans." On the other hand, based on a report from emerging infectious diseases, it states that an increase in rainfall will indirectly result in the spread of enterovirus to millions of people worldwide each year. For example, climate change can cause flash floods, and bring human waste to the sea. When this happens, some of these viruses can contaminate shellfish and if consumed can cause more serious disease rates in humans [30].

The Centers for Disease Control and Prevention (CDC) estimates that three out of every four newly emerging diseases come from animals. Experts have linked the earliest COVID-19 case with the Huanan "wet" market in Wuhan Province, China, where people sell wild animals for their meat to use [31]. A new study published in nature has confirmed that COVID-19 was not made in a laboratory, as some conspiracy theorists say. In contrast, the genome has a striking resemblance to the corona virus in bats, and is similar to the corona virus that infects pangolins. This is consistent with the theory that the virus spread to humans from bats 
through anteaters sold in the Huanan market. Although it is not specific that climate change plays a role in the emergence of COVID-19, it is possible that this virus has a role in human activities.

The spread of COVID-19 is inseparable from social conditions [32]. In Indonesia, the government has issued a state of disaster emergency from 29 February 2020 to 29 May 2020 related to this pandemic virus with a total time of 91 days. Steps have been taken by the government to resolve this extraordinary case, one of which is to socialize the social distancing movement [33]. This concept explains that to be able to reduce or even break the chain of distribution of COVID-19, one must support a safe distance with other humans at least $2 \mathrm{~m}$, and not make direct contact with others, and avoid mass meetings [34], [35], [36].

Indonesia is one of the largest archipelagic countries in the world having around 17,491 islands. The Indonesian archipelago spreads around the equator, and tends to have tropical weather. Indonesian territory is limited by administrative areas, which have very strategic functions. Some of its functions are as an administrative division of power, besides that the administrative area also functions as a determinant of all regional development activities. This is stated in "Guidelines for asserting regional boundaries have been established by the government through Permendagri No. 1 of 2006" [37].

\section{Materials and Methods}

The data used in this study is data from the 2018 PODES (Village Potential) data collection as an independent variable and the average daily increase in the COVID-19 province in Indonesia as the dependent variable. The number of observations used was 83,931 villages. In addition, the data for disadvantaged areas used in this study is information based on "Presidential Regulation No. 131 of 2015 concerning the Determination of Underdeveloped Regions for 2015-2019," using climate average data for 2001-2018, information related to areas traversed by the equator, and markers between villages/kelurahan in Java and outside Java. In addition to climate variables and public facilities, dummy variables are used as independent variables, which are related to the existence/status of the appropriate conditions. Code "1" when the village with conditions that match the observation variable, and code "0" otherwise. This study uses data for the period March 20-April 9 2020, where in that period there was no large-scale social restriction (PSBB), and public activities were still running as usual because there was not much intervention from the government. OLS multiple regression analysis was used at the data processing stage, and continued with Chi-squared
Automatic Interaction Detector (CHAID) analysis to determine climate and social segmentation on the daily spread of COVID-19.

$$
Y=\alpha+\beta_{1} X_{1}+\beta_{2} X_{2}+\beta_{3} X_{3}+\beta_{4} X_{4}+\beta_{5} X_{5}+\beta_{6} X_{6}
$$
$+\beta_{7} X_{7}+\beta_{8} X_{8}+\beta_{9} X_{9}+\beta_{10} X_{10}+\beta_{11} X_{11}+\beta_{12} X_{12}+\beta_{13} X_{13}+$ $\beta_{14} X_{14}+\beta_{15} X_{15}+\beta_{16} X_{16}+\beta_{17} X_{17}+\beta_{18} X_{18}+\beta_{19} X_{19}+\beta_{20} X_{20}$ $+\beta_{21} x_{21}+\beta_{22} x_{22}+\beta_{23} x_{23}+\beta_{24} x_{24}+\varepsilon$

The analysis used next is the CHAID. CHAID generally estimates a single variable, called a dependent variable, which is associated with other variables, called a regressor. CHAID is an iterative technique that tests one by one the independent variable used in the classification, and arranges them based on the level of statistical significance of chi square on the dependent variable (Gallagher, 2000 at Yohanes and Siti, 2006) [38]. CHAID analysis is expected to be able to provide an indicator of priority priorities to be carried out to reduce the growth rate of COVID-19 daily cases.

\section{Results}

From Table 1, the information is obtained that before entering the control variable the $\mathrm{R}$-squared value of $28.90 \%$ and increased to $61.10 \%$ when interacting with four control variables. From the models formed, it is known that the more control variables involved, the better the strength of the model [39]. Similar to regression in positive cases, the Java Island indicator has the greatest impact when included in the model. There are 12 indicators that have the same direction, when before and after the control variable is entered. The poor sanitary environment has the greatest value when compared to other indicators. While the overseas TV broadcasts is an indicator that has the smallest value on the model. Of all the models and indicators, there is only 1 variable that is declared insignificant, namely solar radiation in model 3,4 , and 5 . When viewed through climate variables, it is known that on average, temperature has the greatest role in the daily growth rate of COVID-19, followed duration of sunshine and rainfall. When viewed through public facility, it is known that the indicator of the existence of private banks has the greatest positive impact.

From Table 2, the information is obtained that before entering the control variable R-squared value of $40.10 \%$ and increased to $70.10 \%$ when interacting with 4 control variables. This figure is greater than the regression results in positive cases. From the models formed, it is known that the more control variables involved, the better the strength of the model. The poor sanitary environment has the biggest impact, when it is included in the model. There are eleven indicators that have the same direction, when before and after the control variable is entered. When viewed from climate variables, temperature has the biggest negative impact. 
Table 1: Calculation of climate factor regression and social role in the development of COVID-19 positive cases

\begin{tabular}{|c|c|c|c|c|c|}
\hline Indicators & Model 1 & Model 2 & Model 3 & Model 4 & Model 5 \\
\hline Rainfall & $\begin{array}{l}-0.001^{\star \star \star} \\
(0.000)\end{array}$ & $\begin{array}{l}-0.000^{* * *} \\
(0.000)\end{array}$ & $\begin{array}{l}-0.000^{\star \star \star} \\
(0.000)\end{array}$ & $\begin{array}{l}-0.000^{\star \star *} \\
(0.000)\end{array}$ & 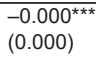 \\
\hline Duration of sunshine & $\begin{array}{l}0.021^{\star \star *} \\
(0.000)\end{array}$ & $\begin{array}{l}-0.001^{\star * *} \\
(0.000)\end{array}$ & $\begin{array}{l}-0.000 \\
(0.000)\end{array}$ & $\begin{array}{l}-0.000 \\
(0.000)\end{array}$ & $\begin{array}{l}-0.000 \\
(0.000)\end{array}$ \\
\hline Temperature & $\begin{array}{l}-0.180^{* * *} \\
(0.003)\end{array}$ & $\begin{array}{l}-0.078^{* \star *} \\
(0.003)\end{array}$ & $\begin{array}{l}-0.079^{\star \star \star} \\
(0.003)\end{array}$ & $\begin{array}{l}-0.079^{\star \star *} \\
(0.003)\end{array}$ & 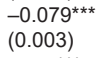 \\
\hline Sanitary environment (Poor) & $\begin{array}{l}0.193^{* \star \star} \\
(0.016)\end{array}$ & $\begin{array}{l}0.109^{\star \star \star *} \\
(0.013)\end{array}$ & $\begin{array}{l}0.109^{\star \star *} \\
(0.013)\end{array}$ & $\begin{array}{l}0.111^{* * *} \\
(0.013)\end{array}$ & $\begin{array}{l}0.111^{\star \star *} \\
(0.013)\end{array}$ \\
\hline Most people use HP & $\begin{array}{l}0.134^{* \star *} \\
(0.004)\end{array}$ & $\begin{array}{l}-0.017^{\star \star \star} \\
(0.002)\end{array}$ & $\begin{array}{l}-0.025^{\star \star \star} \\
(0.002)\end{array}$ & $\begin{array}{l}-0.024^{\star \star *} \\
(0.002)\end{array}$ & 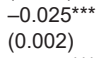 \\
\hline National TV broadcast & $\begin{array}{l}0.098^{\star \star \star *} \\
(0.006)\end{array}$ & $\begin{array}{l}-0.014^{* * *} \\
(0.003)\end{array}$ & 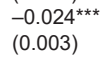 & $\begin{array}{l}-0.020^{\star \star *} \\
(0.003)\end{array}$ & $\begin{array}{l}-0.021^{\text {*** }} \\
(0.003)\end{array}$ \\
\hline Overseas TV broadcasts & $\begin{array}{l}-0.047^{\star * *} \\
(0.005)\end{array}$ & $\begin{array}{l}-0.041^{* * *} \\
(0.003)\end{array}$ & 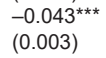 & $\begin{array}{l}-0.043^{* * *} \\
(0.003)\end{array}$ & $\begin{array}{l}-0.043^{\text {***}} \\
(0.003)\end{array}$ \\
\hline Ethnic variety & $\begin{array}{l}-0.156^{\star * *} \\
(0.004)\end{array}$ & $\begin{array}{l}0.052^{\star \star \star} \\
(0.003)\end{array}$ & $\begin{array}{l}0.052^{\star * \star} \\
(0.003)\end{array}$ & $\begin{array}{l}0.053^{\star \star \star} \\
(0.003)\end{array}$ & $\begin{array}{l}0.053^{\star \star \star} \\
(0.003)\end{array}$ \\
\hline Agricultural production facility shop & $\begin{array}{l}-0.060^{* * *} \\
(0.005)\end{array}$ & $\begin{array}{l}0.025^{\star \star \star *} \\
(0.003)\end{array}$ & $\begin{array}{l}0.024^{* * *} \\
(0.003)\end{array}$ & $\begin{array}{l}0.023^{\text {***}} \\
(0.003)\end{array}$ & $\begin{array}{l}0.023^{* * *} \\
(0.003)\end{array}$ \\
\hline Mini market & $\begin{array}{l}0.039^{\star \star \star} \\
(0.006)\end{array}$ & $\begin{array}{l}0.014^{\star \star *} \\
(0.004)\end{array}$ & $\begin{array}{l}0.013^{\star \star *} \\
(0.004)\end{array}$ & $\begin{array}{l}0.013^{\star \star \star} \\
(0.004)\end{array}$ & $\begin{array}{l}0.013^{\star \star \star} \\
(0.004)\end{array}$ \\
\hline Restaurant & $\begin{array}{l}0.014^{\star \star *} \\
(0.003)\end{array}$ & $\begin{array}{l}0.015^{\star \star *} \\
(0.003)\end{array}$ & $\begin{array}{l}0.015^{\star \star *} \\
(0.003)\end{array}$ & 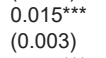 & $\begin{array}{l}0.015^{\star \star \star} \\
(0.003)\end{array}$ \\
\hline Government bank & $\begin{array}{l}0.062^{\star \star *} \\
(0.013)\end{array}$ & $\begin{array}{l}0.049^{\star * *} \\
(0.011)\end{array}$ & $\begin{array}{l}0.049^{* * *} \\
(0.011)\end{array}$ & $\begin{array}{l}0.049^{\star * *} \\
(0.011)\end{array}$ & $\begin{array}{l}0.049^{\star * \star} \\
(0.011)\end{array}$ \\
\hline Private bank & $\begin{array}{l}0.104^{* \star *} \\
(0.022)\end{array}$ & $\begin{array}{l}0.090^{\star \star *} \\
(0.019)\end{array}$ & $\begin{array}{l}0.090^{\star * *} \\
(0.019)\end{array}$ & $\begin{array}{l}0.090^{* * *} \\
(0.019)\end{array}$ & $\begin{array}{l}0.090^{\star \star \star} \\
(0.019)\end{array}$ \\
\hline Development of transportation facilities & 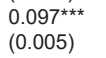 & $\begin{array}{l}0.012^{* * *} \\
(0.003)\end{array}$ & $\begin{array}{l}0.011^{* * *} \\
(0.003)\end{array}$ & 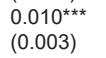 & $\begin{array}{l}0.010^{\star \star *} \\
(0.003)\end{array}$ \\
\hline Development of infor. and communication facilities & $\begin{array}{l}0.108^{* * *} \\
(0.006)\end{array}$ & $\begin{array}{l}-0.019^{* * *} \\
(0.005)\end{array}$ & 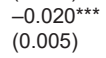 & $\begin{array}{l}-0.020^{\star * *} \\
(0.005)\end{array}$ & $\begin{array}{l}-0.020^{\text {*** }} \\
(0.005)\end{array}$ \\
\hline Development of sanitation facilities & $\begin{array}{l}-0.026^{* * *} \\
(0.005)\end{array}$ & $\begin{array}{l}-0.028^{* * *} \\
(0.003)\end{array}$ & $\begin{array}{l}-0.028^{\star * *} \\
(0.003)\end{array}$ & $\begin{array}{l}-0.028^{* * *} \\
(0.003)\end{array}$ & $\begin{array}{l}-0.028^{* * *} \\
(0.003)\end{array}$ \\
\hline Development of government facilities & $\begin{array}{l}0.090^{* \star *} \\
(0.005)\end{array}$ & $\begin{array}{l}-0.013^{\star \star *} \\
(0.004)\end{array}$ & $\begin{array}{l}-0.013^{* \star *} \\
(0.004)\end{array}$ & $\begin{array}{l}-0.013^{\star \star *} \\
(0.004)\end{array}$ & 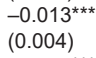 \\
\hline Housing environment empowerment & $\begin{array}{l}-0.006 \\
(0.007)\end{array}$ & $\begin{array}{l}-0.038^{* * *} \\
(0.005)\end{array}$ & $\begin{array}{l}-0.037^{\star \star \star} \\
(0.005)\end{array}$ & $\begin{array}{l}-0.037^{\star \star *} \\
(0.005)\end{array}$ & 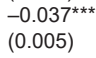 \\
\hline Farming empowerment & $\begin{array}{l}-0.031^{* * *} \\
(0.006)\end{array}$ & $\begin{array}{l}-0.021^{* \star *} \\
(0.004)\end{array}$ & $\begin{array}{l}-0.020^{\star * *} \\
(0.004)\end{array}$ & $\begin{array}{l}-0.020^{\star * *} \\
(0.004)\end{array}$ & $\begin{array}{l}-0.020^{\text {*** }} \\
(0.004)\end{array}$ \\
\hline Community quality empowerment & $\begin{array}{l}0.032^{* * *} \\
(0.005)\end{array}$ & 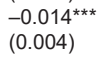 & $\begin{array}{l}-0.015^{\star \star *} \\
(0.004)\end{array}$ & $\begin{array}{l}-0.015^{\star \star *} \\
(0.004)\end{array}$ & 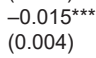 \\
\hline Java island & & $\begin{array}{l}1.072^{\star \star \star} \\
(0.007)\end{array}$ & $\begin{array}{l}1.064^{\star * *} \\
(0.007)\end{array}$ & $\begin{array}{l}1.060^{* \star *} \\
(0.007)\end{array}$ & $\begin{array}{l}1.060^{\star \star \star} \\
(0.007)\end{array}$ \\
\hline Status of underdeveloped areas & & & $\begin{array}{l}-0.029^{\star \star \star *} \\
(0.002)\end{array}$ & $\begin{array}{l}-0.026^{\star \star \star *} \\
(0.002)\end{array}$ & $\begin{array}{l}-0.025^{\star \star \star} \\
(0.002)\end{array}$ \\
\hline Bordering the sea & & & & $\begin{array}{l}-0.026^{\star * *} \\
(0.003)\end{array}$ & $\begin{array}{l}-0.026^{\star * \star} \\
(0.003)\end{array}$ \\
\hline Equator path (Province) & & & & & $\begin{array}{l}-0.003 \\
(0.002)\end{array}$ \\
\hline Constant & $\begin{array}{l}4.144^{\star \star *} \\
(0.086)\end{array}$ & $\begin{array}{l}2.330^{\star * *} \\
(0.067)\end{array}$ & $\begin{array}{l}2.351^{* * *} \\
(0.067)\end{array}$ & $\begin{array}{l}2.350^{\star * *} \\
(0.067)\end{array}$ & $\begin{array}{l}2.349^{* \star *} \\
(0.068)\end{array}$ \\
\hline Observations & 83.931 & 83.931 & 83.931 & 83.931 & 83.931 \\
\hline R-squared & 0.289 & 0.611 & 0.611 & 0.611 & 0.611 \\
\hline
\end{tabular}

The existence Development of sanitation facilities is an indicator that has the smallest value on the model. From the overall model formed, all indicators are declared significant. When viewed through climate variables, it is known that temperature has the most significant role in the daily growth rate of COVID-19 deaths in all models. When viewed through public facility, same as the results in Table 1, it is known that the indicator of the existence of private banks has the greatest positive impact.

Through the CHAID analysis, it was found that the highest ranking of the 5 models included indicators of rainfall, duration of sunshine, temperature, sanitary environment (poor), most people use HP, ethnic diversity, development of transportation facilities, development of government support facilities, and all of territorial variable. The condition is the same between positive cases and cases of death due to COVID-19. Java Island and poor sanitary environment have a very big role in the model, because it always occupies the top position compared to other observational indicators.

When viewed as whole climate variables always give high to the daily growth rate of COVID-19. This can be seen from Figures 1 and 2, climate indicators show a significant role in the priority cluster. Where priority clusters are the clusters that have the greatest impact if they only pay attention to the most important indicators to suppress the daily growth rate of COVID-19.

In Figure 1, when viewed from the role of selected climate factors for all indicators of climate factors, information is obtained that selected climate indicators have a role in the range of $34-88$ percent in model. Where in models 1 and 5 seen a very large role of selected climate indicators for overall climate factors. This indicates that in models 1 and 5 , collaboration of 2-3 climate indicators can make a major contribution to the model formed. In Figure 2, by considering priority clusters, information is obtained that selected climate indicators have a role in the range of $14-89 \%$ in the whole model. Where in models 1 and 4 seen a very large role of selected climate indicators for overall climate factors. This indicates that in models 1 and 5 , collaboration of 2-3 climate indicators can make a major contribution to the model formed. 
Table 2: Calculation of climate factor regression and social role in the development of cases of death due to COVID-19

\begin{tabular}{|c|c|c|c|c|c|}
\hline Indicators & Model 1 & Model 2 & Model 3 & Model 4 & Model 5 \\
\hline Rainfall & $\begin{array}{l}-0.001^{\star \star *} \\
(0.000)\end{array}$ & $\begin{array}{l}-0.000^{* * *} \\
(0.000)\end{array}$ & $\begin{array}{l}-0.000^{\star \star \star} \\
(0.000)\end{array}$ & $\begin{array}{l}-0.000^{\star \star \star} \\
(0.000)\end{array}$ & 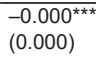 \\
\hline Duration of sunshine & $\begin{array}{l}0.017^{* * *} \\
(0.000)\end{array}$ & $\begin{array}{l}-0.003^{* * *} \\
(0.000)\end{array}$ & $\begin{array}{l}-0.003^{\star \star *} \\
(0.000)\end{array}$ & $\begin{array}{l}-0.003^{\star * *} \\
(0.000)\end{array}$ & $\begin{array}{l}-0.003^{\star \star \star} \\
(0.000)\end{array}$ \\
\hline Temperature & $\begin{array}{l}-0.323^{\star \star *} \\
(0.003)\end{array}$ & $\begin{array}{l}-0.234^{\star * *} \\
(0.002)\end{array}$ & $\begin{array}{l}-0.234^{\star \star *} \\
(0.002)\end{array}$ & 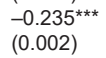 & $\begin{array}{l}-0.233^{\text {***}} \\
(0.002)\end{array}$ \\
\hline Sanitary environment (Poor) & $\begin{array}{l}0.186^{* * *} \\
(0.014)\end{array}$ & $\begin{array}{l}0.113^{* \star *} \\
(0.011)\end{array}$ & $\begin{array}{l}0.113^{* * *} \\
(0.011)\end{array}$ & $\begin{array}{l}0.115^{\star \star *} \\
(0.011)\end{array}$ & $\begin{array}{l}0.115^{\star \star *} \\
(0.011)\end{array}$ \\
\hline Most people use HP & $\begin{array}{l}0.113^{\star \star *} \\
(0.003)\end{array}$ & $\begin{array}{l}-0.018^{\star * *} \\
(0.002)\end{array}$ & $\begin{array}{l}-0.019^{\star \star \star} \\
(0.002)\end{array}$ & $\begin{array}{l}-0.019^{* * *} \\
(0.002)\end{array}$ & 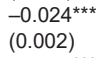 \\
\hline National TV broadcast & 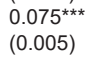 & $\begin{array}{l}-0.023^{\star * *} \\
(0.002)\end{array}$ & $\begin{array}{l}-0.024^{\star \star \star} \\
(0.002)\end{array}$ & 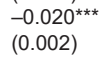 & $\begin{array}{l}-0.030^{\text {*** }} \\
(0.002)\end{array}$ \\
\hline Overseas TV broadcasts & $\begin{array}{l}0.004 \\
(0.004)\end{array}$ & $\begin{array}{l}0.009^{\star * *} \\
(0.002)\end{array}$ & $\begin{array}{l}0.009^{* * *} \\
(0.002)\end{array}$ & $\begin{array}{l}0.009^{* * *} \\
(0.002)\end{array}$ & $\begin{array}{l}0.006^{* * *} \\
(0.002)\end{array}$ \\
\hline Ethnic variety & $\begin{array}{l}-0.156^{\star \star *} \\
(0.003)\end{array}$ & $\begin{array}{l}0.026^{\star \star *} \\
(0.002)\end{array}$ & $\begin{array}{l}0.026^{\star \star *} \\
(0.002)\end{array}$ & 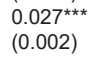 & $\begin{array}{l}0.028^{* \star *} \\
(0.002)\end{array}$ \\
\hline Agricultural production facility shop & $\begin{array}{l}-0.061^{* * *} \\
(0.004)\end{array}$ & $\begin{array}{l}0.013^{\text {*** }} \\
(0.002)\end{array}$ & $\begin{array}{l}0.013^{* * *} \\
(0.002)\end{array}$ & $\begin{array}{l}0.013^{* * *} \\
(0.002)\end{array}$ & $\begin{array}{l}0.012^{* \star *} \\
(0.002)\end{array}$ \\
\hline Mini market & $\begin{array}{l}0.032^{* * *} \\
(0.005)\end{array}$ & $\begin{array}{l}0.010^{\star \star *} \\
(0.003)\end{array}$ & $\begin{array}{l}0.010^{\star \star *} \\
(0.003)\end{array}$ & $\begin{array}{l}0.010^{\star * *} \\
(0.003)\end{array}$ & $\begin{array}{l}0.010^{\star \star \star} \\
(0.003)\end{array}$ \\
\hline Restaurant & $\begin{array}{l}0.011^{\star \star \star} \\
(0.003)\end{array}$ & $\begin{array}{l}0.012^{\star \star \star} \\
(0.002)\end{array}$ & $\begin{array}{l}0.012^{\star \star *} \\
(0.002)\end{array}$ & $\begin{array}{l}0.012^{\star \star \star} \\
(0.002)\end{array}$ & $\begin{array}{l}0.012^{\star \star \star} \\
(0.002)\end{array}$ \\
\hline Government bank & $\begin{array}{l}0.051^{* * *} \\
(0.011)\end{array}$ & $\begin{array}{l}0.039^{* * *} \\
(0.009)\end{array}$ & $\begin{array}{l}0.039^{\star \star *} \\
(0.009)\end{array}$ & $\begin{array}{l}0.039^{* * *} \\
(0.009)\end{array}$ & $\begin{array}{l}0.040^{* \star *} \\
(0.009)\end{array}$ \\
\hline Private bank & $\begin{array}{l}0.089^{* * *} \\
(0.018)\end{array}$ & $\begin{array}{l}0.077^{\star \star *} \\
(0.016)\end{array}$ & $\begin{array}{l}0.077^{\star \star * *} \\
(0.016)\end{array}$ & $\begin{array}{l}0.077^{* * *} \\
(0.016)\end{array}$ & $\begin{array}{l}0.076^{* \star \star} \\
(0.016)\end{array}$ \\
\hline Development of transportation facilities & $\begin{array}{l}0.087^{\star \star \star} \\
(0.004)\end{array}$ & $\begin{array}{l}0.013^{\star \star \star} \\
(0.003)\end{array}$ & $\begin{array}{l}0.012^{* * *} \\
(0.003)\end{array}$ & $\begin{array}{l}0.012^{\star \star *} \\
(0.003)\end{array}$ & $\begin{array}{l}0.012^{\star \star \star} \\
(0.003)\end{array}$ \\
\hline Development of infor. and communication facilities & $\begin{array}{l}0.091^{\star * *} \\
(0.005)\end{array}$ & $\begin{array}{l}-0.020^{* * *} \\
(0.004)\end{array}$ & $\begin{array}{l}-0.020^{\star \star \star} \\
(0.004)\end{array}$ & $\begin{array}{l}-0.020^{\star * *} \\
(0.004)\end{array}$ & $\begin{array}{l}-0.019^{\text {*** }} \\
(0.004)\end{array}$ \\
\hline Development of sanitation facilities & $\begin{array}{l}-0.004 \\
(0.004)\end{array}$ & $\begin{array}{l}-0.006^{\star *} \\
(0.003)\end{array}$ & $\begin{array}{l}-0.006^{* *} \\
(0.003)\end{array}$ & $\begin{array}{l}-0.006^{\star *} \\
(0.003)\end{array}$ & $\begin{array}{l}-0.005^{\star *} \\
(0.003)\end{array}$ \\
\hline Development of government facilities & $\begin{array}{l}0.076^{\text {*** }} \\
(0.004)\end{array}$ & $\begin{array}{l}-0.013^{* * *} \\
(0.003)\end{array}$ & $\begin{array}{l}-0.013^{* * *} \\
(0.003)\end{array}$ & $\begin{array}{l}-0.013^{\text {***}} \\
(0.003)\end{array}$ & $\begin{array}{l}-0.012^{\text {***}} \\
(0.003)\end{array}$ \\
\hline Housing environment empowerment & $\begin{array}{l}0.017^{\text {*** }} \\
(0.006)\end{array}$ & $\begin{array}{l}-0.011^{\star \star *} \\
(0.004)\end{array}$ & $\begin{array}{l}-0.011^{\text {** }} \\
(0.004)\end{array}$ & $\begin{array}{l}-0.011^{* *} \\
(0.004)\end{array}$ & $\begin{array}{l}-0.010^{* *} \\
(0.004)\end{array}$ \\
\hline Farming empowerment & $\begin{array}{l}-0.026^{\star \star *} \\
(0.005)\end{array}$ & $\begin{array}{l}-0.017^{\star \star *} \\
(0.003)\end{array}$ & $\begin{array}{l}-0.017^{\star * \star} \\
(0.003)\end{array}$ & $\begin{array}{l}-0.016^{\star \star \star} \\
(0.003)\end{array}$ & $\begin{array}{l}-0.015^{\star \star \star} \\
(0.003)\end{array}$ \\
\hline Community quality empowerment & 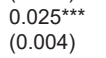 & $\begin{array}{l}-0.015^{\star * *} \\
(0.003)\end{array}$ & $\begin{array}{l}-0.016^{\star \star *} \\
(0.003)\end{array}$ & $\begin{array}{l}-0.015^{\star * *} \\
(0.003)\end{array}$ & 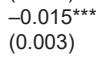 \\
\hline Java island & & $\begin{array}{l}0.935^{\star \star \star} \\
(0.006)\end{array}$ & $\begin{array}{l}0.934^{* \star *} \\
(0.006)\end{array}$ & $\begin{array}{l}0.929^{\star \star *} \\
(0.006)\end{array}$ & $\begin{array}{l}0.927^{\star \star \star} \\
(0.006)\end{array}$ \\
\hline Status of underdeveloped areas & & & $\begin{array}{l}-0.003^{*} \\
(0.002)\end{array}$ & $\begin{array}{l}0.001 \\
(0.002)\end{array}$ & $\begin{array}{l}0.017^{* * *} \\
(0.002)\end{array}$ \\
\hline Bordering the sea & & & & 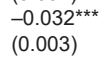 & $\begin{array}{l}-0.031^{\text {*** }} \\
(0.003)\end{array}$ \\
\hline Equator path (Province) & & & & & $\begin{array}{l}-0.053^{\star \star \star} \\
(0.002)\end{array}$ \\
\hline Constant & $\begin{array}{l}8.302^{* * *} \\
(0.072)\end{array}$ & $\begin{array}{l}6.720^{\star \star \star} \\
(0.054)\end{array}$ & $\begin{array}{l}6.722^{* * *} \\
(0.055)\end{array}$ & 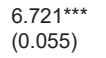 & $\begin{array}{l}6.703^{* \star *} \\
(0.055)\end{array}$ \\
\hline Observations & 83.931 & 83.931 & 83.931 & 83.931 & 83.931 \\
\hline R-squared & 0.401 & 0.699 & 0.699 & 0.699 & 0.700 \\
\hline
\end{tabular}

\section{Discussion}

Climatic and social factors play an important role in the spread of COVID-19 cases. Climate is a natural phenomenon that cannot be denied by living things. However, based on earlier research, climate phenomena can be controlled before worse impacts will occur [40]. This condition of climate change has been felt by all countries in various parts of the world, and will have a negative impact on human life if it is not accompanied by good mitigation.

From the results of the calculation of the regression analysis, with or without control variables, it is known that all variables have a significant effect. Climate variables play a major role in the growth rate of COVID-19, especially in the solar irradiation indicator. In positive cases and dying from COVID-19, temperature has the greatest coefficient, before entering the control indicator. High temperatures can inhibit the growth rate of COVID-19, and this is in accordance with previous research which states that high temperature and high humidity reduce the transmission of COVID-19 [41].
Other things that can be taken into consideration include areas that are at the center of development and the economy tends to be in urban areas, the climate tends to be extreme due to the production process and population mobility. From this phenomenon, it can be concluded that the spread of COVID-19 tends to be slow when it is in an area far from the center of development and the economy and has no extreme duration of sunshine.

Another thing can also be seen from the environmental conditions of the community. In positive and dead cases, poor sanitary conditions will have a positive impact on the spread of COVID-19. The WHO has issued guidelines for the prevention of COVID-19. It is hoped that through this guideline, people can support personal hygiene and the environment. In the application of health protocols in Indonesia, people are asked to wash their hands more often, restrictions on touching public items, and always wear masks when leaving the house.

The condition is quite sad when an area is inhabited by people who mostly use cellphones and their territory is available on a national TV network, 


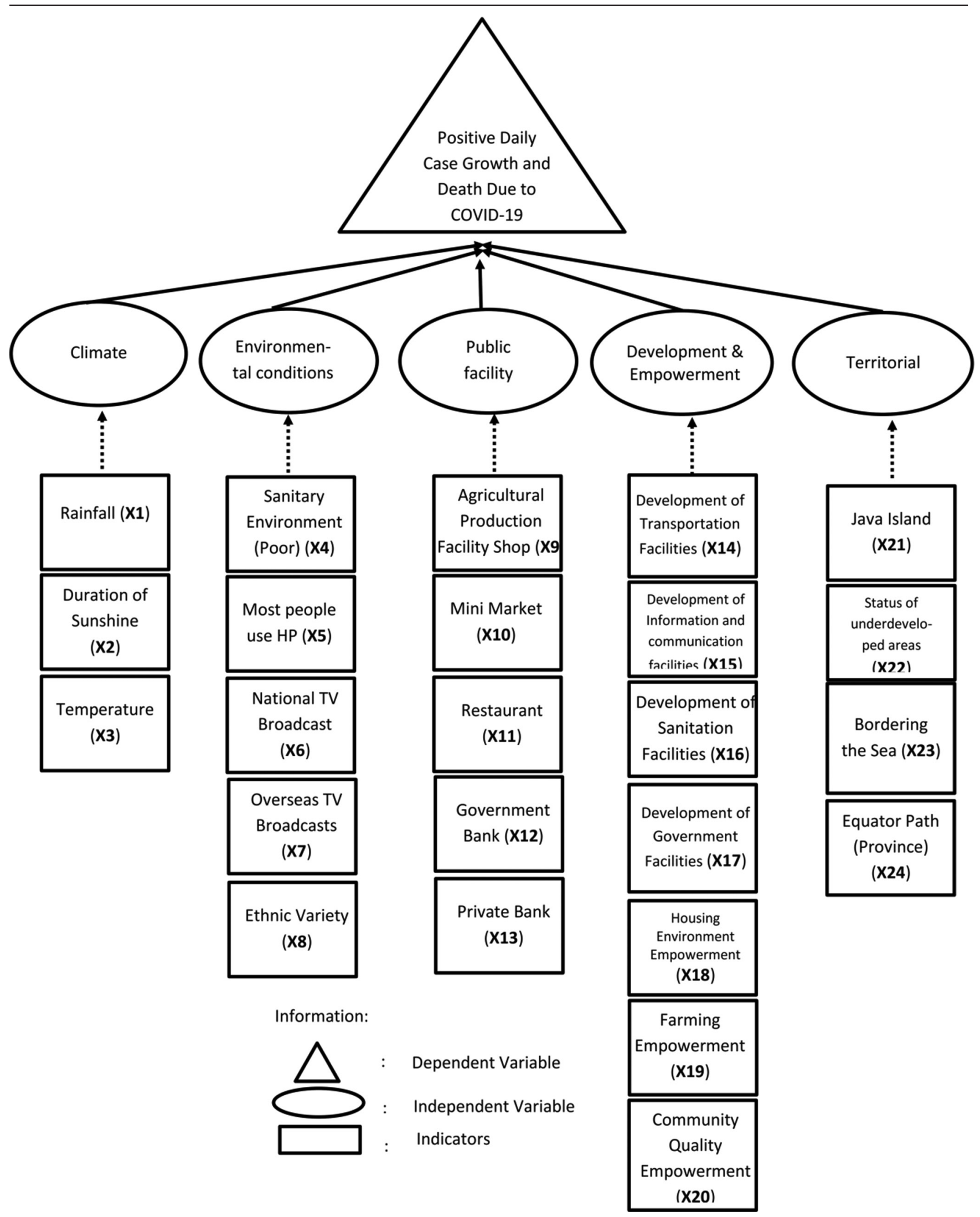

Figure 1: Research conceptual framework

instead the region has a positive impact on the rate of growth, but this is different when an area has an international TV network. Logically, a region that has good sources of information will have a good impact on the rate of spread, but that has not happened in
Indonesia. Ethnic diversity, which indicates urban areas, also has a positive effect when added to the control variable.

Public facilities can be used as indicators of social interaction. More and more public facilities are 


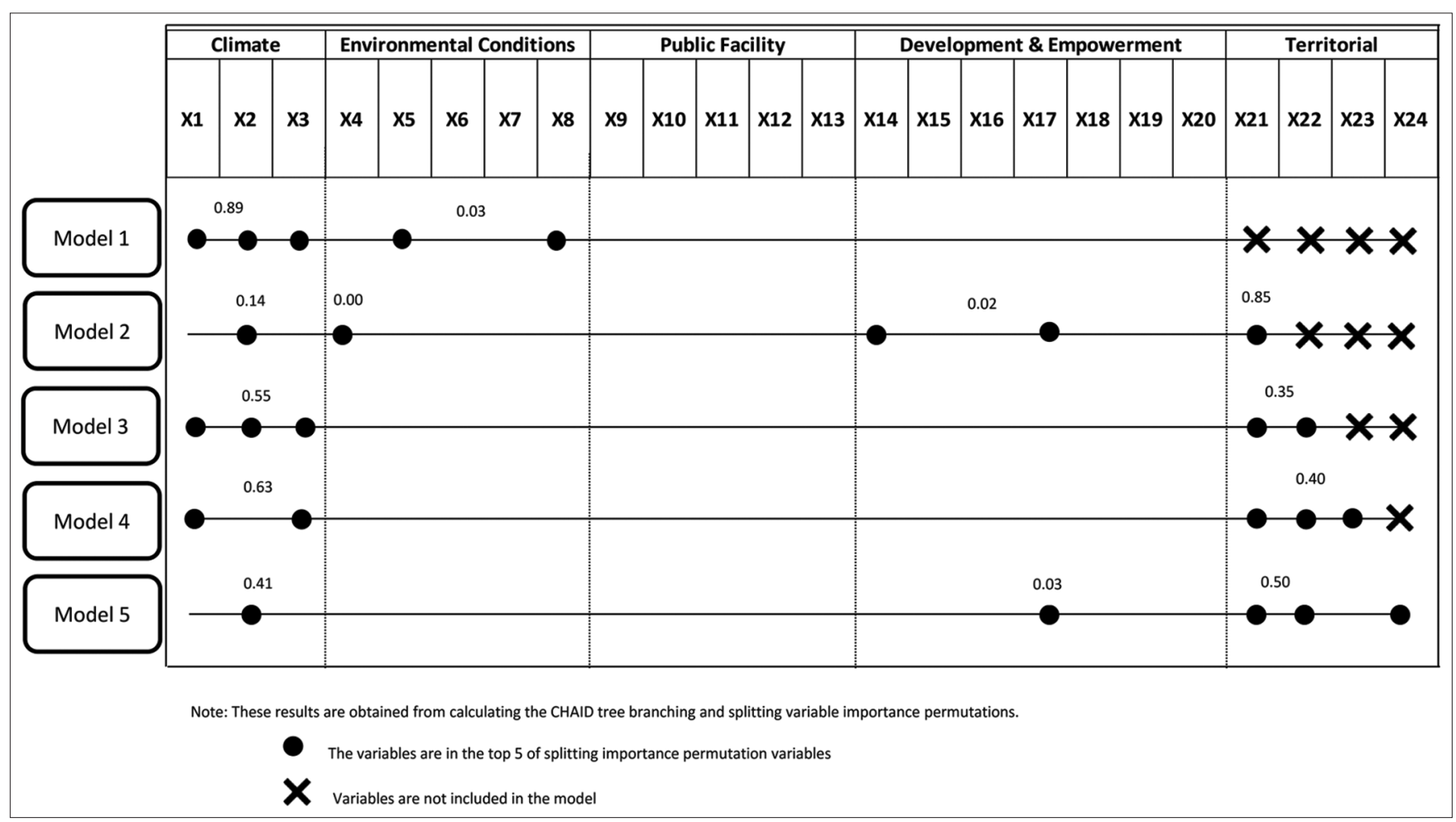

Figure 2: Calculation of priority clusters in patients died due to coronavirus disease-19

being built, indicating that the region has high social interaction. In positive cases and death, it is known that the existence of minimarkets, restaurants, private banks and government banks has a positive influence on the growth rate of COVID-19 in an area. Public facilities will invite people to gather, so that it can cause the spread of viruses with high risk. However, this condition is contrary to the existence of shops that sell agricultural production facilities ini model 1 , which have a negative effect. Stores of agricultural production facilities are more often found in rural areas. Even that shop doesn't invite crowds of people. The intensity of consumers to come to the store, less often than other public facilities on observation.

In the development program and community empowerment, it will show how the interaction created as social capital. On the one hand, this interaction will have a good effect to reduce the growth rate of COVID-19, such as a positive response from the community to remind each other. However, on the other hand, these interactions turned out to have a bad impact. Habits of people to meet and gather with each other will cause negative effects. In areas that carry out community-based development and empowerment programs, only indicators for the development of transportation facilities have an impact on increasing the COVID-19 growth rate for all of model.

Java Island as control variables has a major role in the growth rate of COVID-19. This is clear in the growth of COVID-19 since it first appeared in Indonesia.
Java Island is an island that has a high population density. Besides that, as the center of the economy and development, the existence of a number of economic activities triggers the interaction of a number of people. In the calculation results it is known that, the area around the equator has a negative impact on the growth of COVID-19. This is also shown by indicators of disadvantaged areas and areas bordering the sea. The area with the status of underdeveloped area and the area bordering the sea, is far from the center of the economy and development, so that the region will avoid the rapid growth rate of COVID-19.

The segmentation of the spread of COVID-19 can be seen from Figures 1 and 2 . The growth rate can be reduced through efforts that focus on areas that have high rainfall, Duration of sunshine, high temperatures, ethnic diversity, government facility development programs, community quality empowerment programs, located on the island of Java, and the area is not underdeveloped area. Through this analysis policy makers can decide effective and efficient ways according to the characteristics of the region and existing resources [42].

This study indicates that community and government participation is needed in controlling the growth rate of COVID-19. The community needs to implement the government's appeal. If all people obey the government's call, surely the growth rate of COVID-19 can be suppressed. This study uses climate data at the provincial level, for that in future studies climate data at the village level are needed to get more representative results. 


\section{Conclusion}

COVID-19 is a big challenge for a number of scientists in the world. Until mid-2020 a vaccine against the virus has not been found. Some experts have hypotheses related to climate effects at the country level. By adding social data, we tried to combine climate variables and the daily growth rate of COVID-19 in positive and deceased patients. From the climate side, the temperature indicator has a major role on the growth rate. The higher the temperature will hinder the growth rate. This is in online to some statements that, the more tropical a region is, it will inhibit the spread of COVID-19. Public facilities frequented by the community have a positive role in the rate of spread, especially facilities in urban areas, and has been stated by earlier research [43]. Territorial status is very important to consider when analyzing growth rates. Java Islands as a center of growth and economy has a large share in the spread of COVID-19 growth rates. Through further analysis, it can be seen that the growth rate of COVID-19 can be suppressed through areas that have poor sanitary environment and Java Islands.

\section{References}

1. Maida M, Sferrazza S, Savarino E, Ricciardiello L, Repici A, Morisco $\mathrm{F}$, et al. Impact of the COVID-19 pandemic on gastroenterology divisions in Italy: A national survey. Dig Liver Dis. 2020;52(8):808-15. http://doi.org/10.1016/j.dld.2020.05.017 PMid:32425733

2. Laing T. The economic impact of the coronavirus 2019 (Covid2019): Implications for the mining industry. Extr Ind Soc. 2020;7(2):580-2. http://doi.org/10.1016/j.exis.2020.04.003 PMid:32300537

3. Nghiem LD, Morgan B, Donner E, Short MD. The COVID-19 pandemic: Considerations for the waste and wastewater services sector. Case Stud Chem Environ Eng. 2020;1:100006.

4. Haleem A, Javaid M, Vaishya R, Deshmukh SG. Areas of academic research with the impact of COVID-19. Am J Emerg Med. 2020;38(7):1524-6. http://doi.org/10.1016/j.ajem.2020.04.022 PMid:32317202

5. Millett GA, Jones AT, Benkeser D, Baral S, Mercer L, Beyrer C, et al. Assessing differential impacts of COVID-19 on black communities. Ann Epidemiol. 2020;47:37-44. http://doi. org/10.1016/j.annepidem.2020.05.003

PMid:32419766

6. Rapaccini M, Saccani N, Kowalkowski C, Paiola M, Adrodegari F. Navigating disruptive crises through service-led growth: The impact of COVID-19 on Italian manufacturing firms. Ind Mark Manag. 2020;88:225-37

7. Bashir MF, Ma B, Bilal, Komal B, Bashir MA, Tan D, et al. Correlation between climate indicators and COVID-19 pandemic in New York, USA. Sci Total Environ. 2020;728:138835. http:// doi.org/10.1016/j.scitotenv.2020.138835

PMid:32334162
8. Shi P, Dong Y, Yan H, Zhao C, Li X, Liu W, et al. Impact of temperature on the dynamics of the COVID-19 outbreak in China. Sci Total Environ. 2020;728:138890. http://doi. org/10.1016/j.scitotenv.2020.138890

PMid:32339844

9. Lester PE, Holahan T, Siskind D, Healy E. Policy recommendations regarding skilled nursing facility management of COVID-19: Lessons from New York State. J Am Med Dir Assoc. 2020;21(7):888-92. http://doi.org/10.1016/j. jamda.2020.05.058

PMid:32674814

10. Pradhan D, Biswasroy P, Naik PK, Ghosh G, Rath G. A review of current interventions for COVID-19 prevention. Arch Med Res. 2020;51(5):363-74. http://doi.org/10.1016/j. arcmed.2020.04.020

PMid:32409144

11. Zhang $\mathrm{Y}$, Zhang A, Wang J. Exploring the roles of high-speed train, air and coach services in the spread of COVID-19 in China. Transp Policy. 2020;94:34-42.

12. Hartmann NN, Lussier B. Managing the sales force through the unexpected exogenous COVID-19 crisis. Ind Mark Manag. 2020;88:101-11.

13. Madurai Elavarasan R, Pugazhendhi R. Restructured society and environment: A review on potential technological strategies to control the COVID-19 pandemic. Sci Total Environ. 2020;725:138858. http://doi.org/10.1016/j. scitotenv.2020.138858

PMid:32336562

14. Wang Q, Su M. A preliminary assessment of the impact of COVID-19 on environment a case study of China. Sci Total Environ. 2020;728:138915. https://doi.org/10.1016/j. scitotenv.2020.138915

15. Koon OE. The impact of sociocultural influences on the COVID-19 measures reflections from Singapore. J Pain Symptom Manage. 2020;60(2):e90-2. https://doi.org/10.1016/j. jpainsymman.2020.04.022 PMid:32360238

16. Dubey S, Biswas P, Ghosh R, Chatterjee S, Dubey MJ, Chatterjee S, et al. Psychosocial impact of COVID-19. Diabetes Metab Syndr Clin Res Rev. 2020;14(5):779-88. http://doi. org/10.1016/j.dsx.2020.05.035 PMid:32526627

17. Chao M, Xue D, Liu T, Yang H, Hall BJ. Media use and acute psychological outcomes during COVID-19 outbreak in China. J Anxiety Disord. 2020;74:102248. http://doi.org/10.1016/j. janxdis.2020.102248 PMid:32505918

18. Barro K, Malone A, Mokede A, Chevance C. Management of the COVID-19 epidemic by public health establishments Analysis by the Fédération Hospitalière de France. J Visc Surg. 2020;157(3S1):S19-23. http://doi.org/10.1016/j. jviscsurg.2020.04.011 PMid:32417194

19. Méndez-Arriaga $F$. The temperature and regional climate effects on communitarian COVID-19 contagion in Mexico throughout phase 1. Sci Total Environ. 2020;735:139560. http://doi. org/10.1016/j.scitotenv.2020.139560

PMid:32464409

20. Tosepu R, Gunawan J, Effendy DS, Ahmad LO, Lestari H, Bahar H, et al. Correlation between weather and Covid-19 pandemic in Jakarta, Indonesia. Sci Total Environ. 2020;725:138436. http:// doi.org/10.1016/j.scitotenv.2020.138436 PMid:32298883

21. Ma $Y$, Zhao $Y$, Liu J, He X, Wang B, Fu S, et al. Effects of temperature variation and humidity on the death of COVID-19 in 
Wuhan, China. Sci Total Environ. 2020;724:138226. http://doi. org/10.1016/j.scitotenv.2020.138226

PMid:32408453

22. Iqbal N, Fareed Z, Shahzad F, He X, Shahzad U, Lina M. The nexus between COVID-19, temperature and exchange rate in Wuhan city: New findings from partial and multiple wavelet coherence. Sci Total Environ. 2020;729:138916.

23. Kanniah KD, Kamarul Zaman NA, Kaskaoutis DG, Latif MT. COVID-19's impact on the atmospheric environment in the Southeast Asia region. Sci Total Environ. 2020;736:139658. https://doi.org/10.1016/j.scitotenv.2020.139658

24. Ahmed M. In: Dessler AE, editor. Introduction to Modern Climate Change. Cambridge: Cambridge University Press; 2011. p. 252.

25. Schwartz SA. Climate change, Covid-19, preparedness, and consciousness. Explore. 2020;16(3):141-4. https://doi. org/10.1016/j.explore.2020.02.022

PMid:32241685

26. Şahin M. Impact of weather on COVID-19 pandemic in Turkey. Sci Total Environ. 2020;728:138810. https://doi.org/10.1016/j. scitotenv.2020.138810

PMid:32334158

27. Menebo MM. Temperature and precipitation associate with Covid-19 new daily cases: A correlation study between weather and Covid-19 pandemic in Oslo, Norway. Sci Total Environ. 2020;737:139659. https://doi.org/10.1016/j. scitotenv.2020.139659

PMid:32492607

28. Qi H, Xiao S, Shi R, Ward MP, Chen $\mathrm{Y}$, Tu W, et al. COVID-19 transmission in Mainland China is associated with temperature and humidity: A time-series analysis. Sci Total Environ. 2020;728:138778. https://doi.org/10.1016/j. scitotenv.2020.138778 PMid:32335405

29. Shahzad F, Shahzad U, Fareed Z, Iqbal N, Hashmi SH, Ahmad F. Asymmetric nexus between temperature and COVID-19 in the top ten affected provinces of China: A current application of quantileon-quantile approach. Sci Total Environ. 2020;736:139115. https://doi.org/10.1016/j.scitotenv.2020.139115

30. Freeman MC, Garn JV, Sclar GD, Boisson S, Medlicott K, Alexander KT, et al. The impact of sanitation on infectious disease and nutritional status: A systematic review and metaanalysis. Int J Hyg Environ Health. 2017;220(6):928-49. https:// doi.org/10.1016/j.ijheh.2017.05.007

PMid:28602619

31. Mizumoto K, Kagaya K, Chowell G. Effect of a wet market on coronavirus disease (COVID-19) transmission dynamics in
China, 2019-2020. Int J Infect Dis. 2020;97:96-101. https://doi. org/10.1016/j.jijd.2020.05.091

PMid:32497812

32. Buana DR. Analysis of the behavior of Indonesian communities in dealing with the corona virus pandemic (Covid-19) and tips for maintaining life welfare. SALAM J Sos dan Budaya Syar-i. 2020;7(3):217-26.

33. Katz JN, Sinha SS, Alviar CL, Dudzinski DM, Gage A, Brusca SB, et al. COVID-19 and disruptive modifications to cardiac critical care delivery: JACC review topic of the week. J Am Coll Cardiol. 2020;76(1):72-84. https://doi.org/10.1016/j.jacc.2020.04.029 PMid:32305402

34. Min-Allah N, Alrashed S. Smart campus a sketch. Sustain Cities Soc. 2020;59:102231. https://doi.org/10.1016/j.scs.2020.102231 PMid:32395421

35. Shah AU, Safri SN, Thevadas R, Noordin NK, Rahman AA, Sekawi Z, et al. COVID-19 outbreak in Malaysia: Actions taken by the Malaysian government. Int J Infect Dis. 2020;97:108-16. http://doi.org/10.1016/j.ijid.2020.05.093

PMid:32497808

36. Beaunoyer E, Dupéré S, Guitton MJ. COVID-19 and digital inequalities: Reciprocal impacts and mitigation strategies. Comput Human Behav. 2020;111:106424. http://doi. org/10.1016/j.chb.2020.106424 PMid:32398890

37. Nugroho H. Study on implementation of city/regency administrative boundary setting method. Rekayasa J Teknol. 2011;15:19-26.

38. Yohanes SK, Siti NH. CHAID analysis as a statistics tool for market segmentation (Case study in Al-Hidayah Sharia Cooperative). Jur Manaj Pemasar. 2006;1:88-97.

39. Atinc G, Simmering MJ, Kroll MJ. Control variable use and reporting in macro and micro management research. Organ Res Methods. 2012;15(1):57-74.

40. Loo YY, Billa L, Singh A. Effect of climate change on seasonal monsoon in Asia and its impact on the variability of monsoon rainfall in Southeast Asia. Geosci Front. 2015;6(6):817-23.

41. Wang J, Tang K, Feng K, Lv W. High temperature and high humidity reduce the transmission of COVID-19. SSRN Electron J. 2020;11:1-22.

42. Mihaiu DM, Opreana A, Cristescu MP. Efficiency, effectiveness and performance of the public sector. Rom $\mathrm{J}$ Econ Forecast. 2010;13:132-147.

43. Nicola M, Alsafi Z, Sohrabi C, Kerwan A, Al-Jabir A, losifidis C, et al. The socio-economic implications of the coronavirus pandemic (COVID-19): A review. Int J Surg. 2020;78:185-93. http://doi.org/10.1016/j.ijsu.2020.04.018

PMid:32305533 